\title{
An Exploratory Study of School Psychology Students' Perceptions of Religious and Spiritual Diversity Training in their Graduate Programs
}

\author{
Janise S. Parker ${ }^{1} \cdot$ Kate Murray $^{1} \cdot$ Riley Boegel $^{1} \cdot$ Madeline Slough $^{1} \cdot$ Lee Purvis $^{2} \cdot$ Christie Geiling $^{1}$
}

Accepted: 23 August 2021

(C) California Association of School Psychologists 2021, corrected publication 2021

\begin{abstract}
Religiosity and spirituality are essential aspects of individuals' cultural identities. However, the field of school psychology has generally avoided in-depth discussion regarding the implications of religious/spiritual diversity within the context of multiculturalism and culturally responsive practice. One aim of this study was to examine school psychology students' perceptions of their current training relative to religious and spiritual diversity, because graduate training is critical for helping emerging practitioners develop attitudes, knowledge, and skills to employ culturally responsive services. Results showed that students received limited preparation and explicit teaching to address issues related to religious and spiritual diversity; and programs most frequently addressed disability diversity, socioeconomic diversity, and racial/ethnic diversity. Furthermore, the participants most frequently identified practicum experiences as facilitating their capacity to respond to religious and spiritual diversity in their professional practice. Key results suggest that school psychology graduate students may benefit from more explicit instruction during their graduate training to respond to religion and spirituality as aspects of cultural diversity in their professional work.
\end{abstract}

Keywords Competencies $\cdot$ Religion $\cdot$ Spirituality $\cdot$ School psychology $\cdot$ Training $\cdot$ Students

School psychologists are obligated to respond to clients' cultural backgrounds when providing services in their professional practice (American Psychological Association [APA], 2017; National Association of School Psychologists [NASP], 2020). Though key practice standards indicate a need for school psychologists to respond to multiple aspects of culture and human diversity (e.g., race/ethnicity, sexual orientation, age, etc.), issues pertaining to religious and spiritual diversity have received less attention within the profession (e.g., Parker et al., 2020). The lack of discussion surrounding religion and spirituality is detrimental to the field, considering that youth, families, and educators will have various religious/spiritual beliefs that inform how they perceive and interact with the world around them, including

Janise S. Parker

jparker@wm.edu

1 School Psychology and Counselor Education Department, School of Education, William \& Mary, P. O. Box 8795, Williamsburg, VA 23185, USA

2 Louisiana State University Shreveport, Shreveport, LA, USA
K through 12 schools. For example, some families may be hesitant to utilize educational and psychological support due to a preference to utilize religious and spiritual support systems (e.g., Goforth et al., 2017a, 2017b; Parker \& Hanson, 2019), a phenomenon that may be particularly true for racial/ethnic minoritized individuals (Haboush, 2007; Hodge et al., 2009; Kouyoumdjian et al., 2003; Taylor et al., 2000).

At the student level, seminal research shows that religiosity and spirituality among school-age youth is associated with their social, emotional, and behavioral development (Kim \& Esquivel, 2011). For example, research shows that students who report higher levels of religiosity and spirituality are (a) more likely to experience indicators of positive well-being (e.g., happiness, academic achievement, and prosocial interactions) and (b) less likely to experience symptoms related to psychopathology (e.g., anxiety, depression, stress, discipline problems, risk taking behaviors, substance use; AbdelKhalek, 2007; Cotton et al., 2005; Goforth et al., 2016; Hardy \& Raffaelli, 2003; Hodge et al., 2009; Park \& Bonner, 2008; Sinha et al., 2007; Tynan et al., 2015). Consequently, students may elect to utilize religious and spiritual resources to cope 
with grief, trauma, and other social-emotional/behavioral challenges (e.g., Dill, 2017; Jerome, 2011).

Still, some students may experience emotional distress as a result of experiencing religious/spiritual issues, such as feeling punished by God, being obsessed with salvation, or trying to reconcile the tension between their sexual orientation, gender identity and religious/spiritual identity (Kim \& Esquivel, 2011; Wagener \& Mahoney, 2006; Yarhouse \& Tan, 2005). Furthermore, certain groups of youth may experience bullying and harsh treatment at school, including students who are in the minority based on their religious/spiritual affiliation (Atwal \& Wang, 2019; Dupper et al., 2015) and students whose sexual orientation and gender identity are presumed to be antithetical to particular religious/spiritual beliefs (Newman et al., 2018). Though peers may be the perpetrators of these behaviors, research shows that the beliefs tied to a teacher's religion may also negatively impact youth in school (Dupper et al., 2015; Parker \& Hanson, 2019). For instance, a school psychologist who participated in the study conducted by Parker and Hanson (2019) explained that she encountered difficulties consulting with a high school teacher who refused to refer to a transgender female by her chosen name due to the teacher's religious beliefs. Likewise, religious/spiritual minoritized youth who participated in Dupper et al.'s (2015) study described their experiences with classroom teachers who were unsupportive of the students' religious/spiritual beliefs and practices as non-Christian individuals.

Collectively, these experiences highlight a need for school psychologists to be well-prepared to address issues related to religious/spiritual diversity within their professional work. Researchers have developed religious/spiritual practice competencies for psychology practitioners and students (Vieten et al., 2016; Vogel et al., 2013); however, no studies have examined school psychology graduate students' perceptions relative to these two aspects of human diversity. The purpose of this study was to explore school psychology graduate students' perceptions of their training relative to responding to religious and spiritual diversity in their professional practice.

\section{Religion and Spiritual Practice Competencies}

In the last 20 years, scholars have expanded the knowledge base pertaining to multicultural practice in psychology by underscoring the importance of religion and spirituality as critical areas to attend to when serving clients in health service psychology fields (Vieten et al., 2013). As described by Vieten et al. (2013), researchers have generally included recommendations for psychologists to (a) affirm and respect clients' religious and spiritual worldviews, (b) understand how these factors impact clients, (c) design interventions that are responsive to clients' religious and spiritual worldviews, (d) avoid pathologizing clients' religious and spiritual worldviews, and (e) work within the scope one's professional competence (which includes referring clients to religious leaders when needed). Hence, after completing a comprehensive review of seminal scholarship and receiving feedback from experts and practitioners in the field (including master and doctoral-level mental health providers), Vieten et al. (2013) developed a preliminary list of competencies for supporting religiously and spiritually diverse clients as a practicing psychologist.

The competencies were further vetted by practitioners in a follow-up study (Vieten et al., 2016), resulting in the final list of 16 competencies (see Fig.1) that are organized under three common domains of cross-cultural practice (Sue et al., 1992)—attitudes (items 1-3), knowledge (items 4-10), and skills (items 11-16). Attitudes and beliefs generally refer to the perceptions and biases practitioners hold about clients from different cultural backgrounds and the implications of such in their professional practice. Knowledge includes one's understanding of different worldviews and life experiences among cross-cultural groups, of sociopolitical issues and institutional barriers that impact client's outcomes and experiences, of different family structures and community characteristics, and of potential biases in traditional service delivery. Finally, the skills domain is reflected in the practitioners' use of specific techniques when working with clients from different cultural backgrounds (Sue et al., 1992).

Although school psychology is categorized as a health service psychology field alongside clinical and counseling psychology, school psychologists have not been represented in the body of literature regarding religious and spiritual practice competencies. Thus, Parker (2019) surveyed 121 practicing psychologists to examine their perceptions of the proposed competencies. Parker found that approximately $87 \%$ of participants viewed the competencies as somewhat or very important to the field of school psychology, suggesting that Vieten et al.'s (2016) competencies may some have merit for guiding the practice of school psychologists.

Nevertheless, research conducted by Parker et al. (2020) and Parker and Hanson (2019) suggest that the competencies proposed by Vieten et al. (2016) may be limited in scope, considering school psychologists' role in providing comprehensive services. The competencies proposed by Vieten et al. (2016) are framed within the context of providing direct intervention (e.g., counseling support), yet school psychologists are likely to spend most of their time conducting assessments and providing consultation services (Castillo et al., 2012). Indeed, in a qualitative study examining school psychologists' experiences with responding to religious and spiritual diversity in their professional practice, Parker and Hanson (2019) found that Vieten et al.'s (2016) competencies were not fully aligned with participants' engagement in school-based consultation. Furthermore, Vieten et al. (2016) did not detail implications for assessment practices, although 


\begin{tabular}{|c|c|}
\hline $\begin{array}{l}\text { Vieten et al.'s } \\
\quad(2016) \\
\text { Competencies }\end{array}$ & 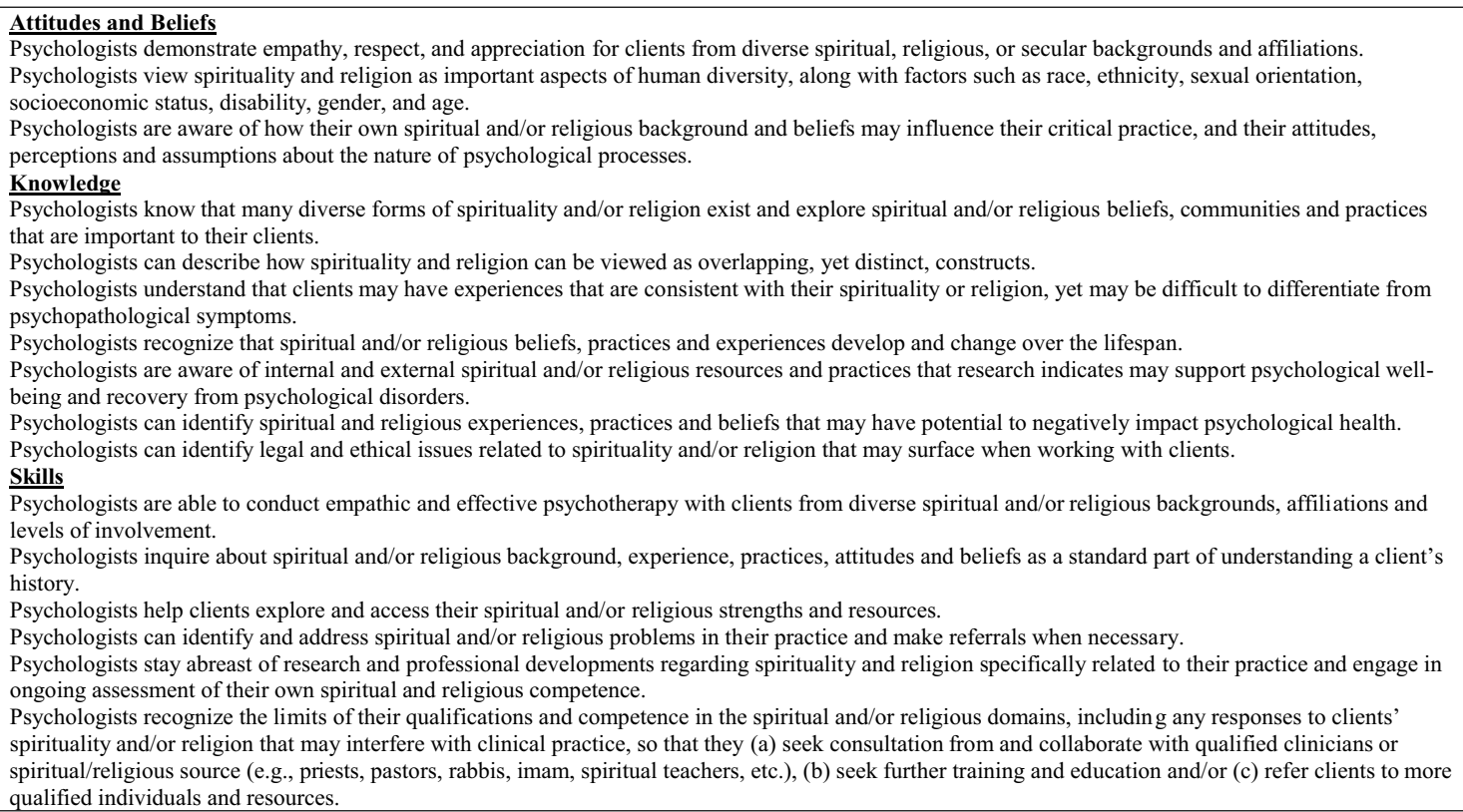 \\
\hline $\begin{array}{c}\text { Vogel et al.'s } \\
\text { (2013) } \\
\text { Advanced } \\
\text { Competencies }\end{array}$ & $\begin{array}{l}\text { Ethical guidelines and professional standards for religion/spirituality. } \\
\text { Case conceptualization in light of clients' religious/spiritual values. } \\
\text { Assessment methods that consider religion/spirituality in clients' lives. } \\
\text { Implementing religious/spiritual interventions in clinical work. } \\
\text { Countertransference issues with religiously/spiritually committed clients. } \\
\text { Self-reflective practices during work with religious/spiritual clients. } \\
\text { Conducting research that is sensitive to religious/spiritual diversity. } \\
\text { Understanding the major world religions/spiritualities. } \\
\text { Consultation skills related to religious/spiritual diversity. } \\
\text { Interdisciplinary collaboration with religious/spiritual leaders. } \\
\text { Considering religion/spirituality when determining if behavior is abnormal. } \\
\text { Views of personhood from the perspectives of major religions/spiritualities. }\end{array}$ \\
\hline
\end{tabular}

Fig. 1 Summary of Vieten et al.'s (2016) and Vogel et al.'s (2013) religious and spiritual diversity competencies

school psychology scholars have emphasized the importance of school psychologists seeking to understand youths and families' religious/spiritual belief systems to inform intervention implementation and respond to their needs (Goforth et al., 2016, 2017a; Haboush, 2007; Jerome, 2011; Suzuki et al.,2006).

Additional competencies developed by Vogel and colleagues (2013) may serve as a useful supplement to Vieten et al.'s (2016) competencies. Vogel et al. proposed a set of advanced competencies to inform APA training programs' focus on religious and spiritual diversity in a more comprehensive manner. The advanced competencies include 12 items that are intended to address the breadth of practice areas in which religious and spiritual diversity issues may arise (e.g., assessment, ethics, consultation, etc.). Additional items on their competence survey focus on (a) how students develop knowledge and skills relative to religious and spiritual diversity in their graduate programs (e.g., coursework, practicum/internship), and (b) the extent to which psychology programs focus on various aspects of human diversity (e.g., race/ethnicity, socioeconomic status, gender, religion/ spirituality, etc.). See Fig.1 for both sets of competencies.

\section{Training and Research Gaps}

As a foundation to one's multicultural practice, researchers are increasingly examining the extent of psychology students' graduate training relative to religious/spiritual diversity (McMinn et al., 2015; Schafer et al., 2011; Vogel et al., 2013). However, most of the research to date has focused on clinical and counseling training programs to the exclusion of school psychology. For example, Vogel et al. (2013) surveyed 532 doctoral students, doctoral level faculty, and clinical training directors in clinical and counseling psychology programs to investigate the extent to which multicultural training focused on religion and spirituality. Overall, the researchers found that programs most often focused on racial/ethnic diversity, socioeconomic diversity, and gender diversity, and least often focused on religious/spiritual diversity. Participants also provided a range of responses relative to the 12 practice competencies, indicating that programs were most likely to equip their trainees with skills for considering religion/spirituality when determining whether behavior is abnormal and least likely to equip their trainees with skills for engaging in interdisciplinary collaboration with religious/spiritual leaders. Finally, respondents 
identified practicum experiences as the most frequent source of learning and coursework as the least frequent source of learning with respect to developing skills for addressing religious/spiritual diversity in their professional work.

Vieten et al. (2016) surveyed 222 practicing mental health providers to understand their perceptions of the 16 competencies, including the extent to which they perceived their graduate programs as preparing students to execute the competencies in practice. Most of the participants were doctorallevel psychologists (93.2\%), with the remaining participants being master-level therapists. Approximately $70 \%$ of participants reported they received little or no explicit training in religious/spiritual diversity. Vieten et al.'s (2016) research parallels findings reported by Vogel et al. (2013) regarding the limited focus on religion/spirituality in psychology-related training programs. However, it is unclear how findings in either study apply to school psychology training programs, because the researchers did not specify the sub-fields of practice represented among the doctoral-level participants. Furthermore, specialist level school psychologists were not included in the studies.

\section{School Psychology as a Unique Field}

Unlike clinical and counseling psychology, most school psychologists hold a specialist degree; and a specialist level practitioner's training is typically limited to approximately two years of coursework and one full year of internship. Restricted time, then, may prevent school psychology programs from addressing these two areas of diversity in a comprehensive manner for non-doctoral students. Furthermore, most school psychologists are likely to work in public school settings and concerns about the separation of church and state may preclude school-based practitioners from responding to these two areas of cultural diversity (Magaldi-Dopman \& Park-Taylor, 2014).

Taking these factors into consideration, research focused on school psychologists exclusively has begun to emerge in the last two years (Parker, 2019; Parker \& Hanson, 2019). Relative to the focus of the current study, $60 \%$ of school psychologists in Parker's (2019) study reported they mostly or completely possessed each competency outlined by Vieten et al. (2016). Such a finding suggests that school psychologists may receive adequate training to execute the competencies in practice. However, little is known about the role of graduate programs as a contributor to practitioners' competence relative to religious and spiritual diversity. Because foundational training for multicultural practice in school psychology occurs at the graduate level (Newell et al., 2010), additional research is needed to understand school psychology trainees' perceptions of their training experiences relative to religious and spiritual diversity competencies.

\section{Purpose of the Study}

Considering the gaps in the current literature, we examined graduate students' perceptions of the extent to which school psychology training programs explicitly taught the 16 basic multicultural competencies proposed by Vieten et al. (2016) and equipped graduate students with knowledge and skills for employing the 12 advanced practice competencies proposed by Vogel et al. (2013). We also examined graduate students' perceptions of the sources of learning school psychology training programs most frequently used to prepare students to respond to religious/spiritual diversity in practice (e.g., practicum, exposure to research, coursework). Finally, we examined the extent to which students perceived their training programs as focusing on religious/spiritual diversity relative to other areas of diversity (e.g., race/ethnicity). Based on prior research indicating that the field of school psychology may focus on racial/ethnic diversity and socioeconomic more frequently than religious/spiritual diversity (Parker et al., 2020), we hypothesized that graduate students may perceive their programs as focusing on those aspects of human diversity more often than religious/spiritual diversity.

\section{Method}

\section{Participants}

The graduate students who completed the survey $(N=114)$ averaged 28.1 years old $(S D=6.2)$ and most participants identified as female $(n=94,82.5 \%)$. Of the participants who reported their racial/ethnic identity, $79.9 \%$ identified as White/European American $(n=91)$.

The respondents varied in their spiritual and religious affiliation, with $41.2 \%(n=47)$ identifying as both religious and spiritual and $47.4 \%$ of participants reporting an affiliation with the Christian-Protestant faith $(n=54)$. Regarding the participants' degree track, most individuals were pursuing the specialist level degree $(n=55,48.2 \%)$ and $93.0 \%$ of the participants $(n=106)$ were enrolled in a school psychology program that was NASP-approved and/or APA-accredited. The participants' programs were in every region within the U. S., with most participants studying in the Southeast $(n=47,41.2 \%)$. See Table 1 for additional demographic information.

We asked respondents to provide demographic information and complete two scales measuring their perceptions of their training relative to religious and spiritual diversity. For the current study, the stem of the items and directions were changed to specifically reference the practice of school psychology as opposed to general psychological practice. 
Survey of Basic Spiritual and Religious Competencies We utilized an adapted version of the measure Vieten et al. (2016) developed to assess psychologists' perceptions of their training relative to the 16 basic spiritual and religious competencies. Because we surveyedcurrent school psychology students, we asked participants to rate the extent to which they perceived themselves as receiving explicit training in each of the competencies using a 4-point Likert-type scale $(1=I$ have not received any explicit training in this domain, $2=I$ have received a little bit explicit training in this domain, $3=I$ have received some explicit training in this domain, $4=I$ have received comprehensive formal training in this domain). Considering our exclusive sample of school psychology trainees, we added the term "school" to the beginning of each item and inserted the term "students" in parentheses next to the term "clients."

Survey of Advanced Spiritual and Religious Competencies To assess school psychology graduate students' training relative to (a) the 12 advanced spiritual and religious competencies, (b) different areas of human diversity, and (c) specific learning sources to prepare students for professional work focused on religious/spiritual diversity, we utilized the survey instrument developed by Vogel et al. (2013). First, participants were asked to rate the degree to which they perceived their graduate programs as equipping them with knowledge and skills for addressing the 12 advanced spiritual and religious competencies and responding to different areas of human diversity in their professional practice (e.g., race/ethnicity, sexual orientation, religious/spiritual diversity) using a 5-point Likert-type scale ( $1=$ strongly disagree, $2=$ disagree, $3=$ neutral, $4=$ agree, $5=$ strongly agree ). Again, we inserted the term "students" in parentheses next to the term "clients." Next, we asked participants to indicate how frequently their program used different sources of learning to prepare students to respond to religious and spiritual diversity in their professional work. Items were presented using a 5 -point Likert-type scale $(1=$ never, $2=$ rarely, $3=$ sometimes, $4=$ often, $5=$ always $)$.

\section{Procedures}

We obtained approval to conduct this study by the Institutional Review Board (IRB). Participants had to be current school psychology graduate students who were 18 or older to partake in this study. After receiving IRB approval, we recruited school psychology graduate students through the Trainers of School Psychology listserv where graduate faculty in school psychology training programs were asked to share the link to the description of study procedures and the surveys. All potential research participants were provided an electronic copy of the recruitment letter describing our study and directions for providing informed consent. We also
Table 1 Participants' demographic characteristics

\begin{tabular}{|c|c|c|}
\hline Demographic Characteristic & $n$ & $\%$ \\
\hline \multicolumn{3}{|l|}{ Sex } \\
\hline Female & 94 & $82.5 \%$ \\
\hline Male & 12 & $10.5 \%$ \\
\hline Non-Binary & 2 & $1.8 \%$ \\
\hline Trans male & 1 & $0.9 \%$ \\
\hline \multicolumn{3}{|l|}{ Racial/Ethnic Identity } \\
\hline White/European American & 91 & $79.9 \%$ \\
\hline Black/African American & 5 & $4.4 \%$ \\
\hline White/Hispanic & 5 & $4.4 \%$ \\
\hline Asian/Asian American & 5 & $4.4 \%$ \\
\hline Mexican/Mexican American & 2 & $1.8 \%$ \\
\hline Multiracial/ethnic background & 2 & $1.8 \%$ \\
\hline Haitian American & 1 & $0.9 \%$ \\
\hline Latino & 1 & $0.9 \%$ \\
\hline Pakistani & 1 & $0.9 \%$ \\
\hline Polish & 1 & $0.9 \%$ \\
\hline \multicolumn{3}{|l|}{ Religious/Spiritual Identity } \\
\hline Religious and Spiritual & 47 & $41.2 \%$ \\
\hline Spiritual but not Religious & 36 & $31.6 \%$ \\
\hline Neither Religious nor Spiritual & 22 & $19.3 \%$ \\
\hline Religious but not Spiritual & 2 & $1.8 \%$ \\
\hline \multicolumn{3}{|l|}{ Religious Affiliation } \\
\hline Christian-Protestant & 54 & $47.4 \%$ \\
\hline Catholicism & 16 & $14.0 \%$ \\
\hline No Affiliation & 8 & $7.0 \%$ \\
\hline Judaism & 5 & $4.4 \%$ \\
\hline Mormonism & 4 & $3.5 \%$ \\
\hline Atheism & 4 & $3.5 \%$ \\
\hline Agnosticism & 2 & $1.8 \%$ \\
\hline Paganism & 2 & $1.8 \%$ \\
\hline Shamanism & 2 & $1.8 \%$ \\
\hline Islam & 1 & $0.9 \%$ \\
\hline Buddhism & 1 & $0.9 \%$ \\
\hline Apatheism & 1 & $0.9 \%$ \\
\hline Orthodox & 1 & $0.9 \%$ \\
\hline \multicolumn{3}{|l|}{ Degree Track } \\
\hline Specialist & 55 & $48.2 \%$ \\
\hline Doctorate & 52 & $45.6 \%$ \\
\hline Masters & 7 & $6.1 \%$ \\
\hline \multicolumn{3}{|l|}{ Year in the Program } \\
\hline Second & 47 & $41.2 \%$ \\
\hline Third & 43 & $37.7 \%$ \\
\hline Fourth (and beyond) & 24 & $21.1 \%$ \\
\hline \multicolumn{3}{|l|}{ Program U.S. Region } \\
\hline Southeast & 47 & $41.2 \%$ \\
\hline West & 18 & $15.8 \%$ \\
\hline Northeast & 17 & $14.9 \%$ \\
\hline Midwest & 15 & $13.2 \%$ \\
\hline Southwest & 15 & $13.2 \%$ \\
\hline
\end{tabular}


informed graduate students that participating in the research study was completely voluntary and they could choose to withdraw at any time. Up to three school psychology graduate students were entered in a drawing to receive a $\$ 10.00$ gift card as a token of appreciation for their participation. Each participant completed an online Qualtrics survey, lasting approximately 15 to $20 \mathrm{~min}$. Prior to answering the survey items, we provided a working definition of key termsspiritual, religious, and competence-to minimize potential confusion among the respondents (Vieten et al., 2016). It is important to note that additional rounds of survey distribution did not occur, because this study was executed right before higher education learning institutions transitioned to remote learning due to the COVID-19 pandemic. Thus, this study is exploratory in nature, considering the unexpected disruption during data collection.

\section{Overview of Data Analysis Plan}

A total of 153 participants were originally included in this study. However, seven of the cases had missing data on one or more survey items. Given that less than $10 \%$ of the data were missing, we removed those cases from data analysis. We also removed the 32 participants who were in the first year of training. This decision was made after our team conducted a preliminary analysis to examine differences in total scores on each set of competencies, based on the participants' year of training (year 1, year 2, year 3, year 4+). The results of this analysis revealed that students in year 1 reported significantly lower scores regarding the extent to which they received diversity training relative to each set competencies. This finding could be explained by the timing of data collection (middle of the spring semester) and due to the abrupt change in higher education due to COVID-19, wherein the first-year students had not received a full-year of typical instruction. Thus, the final sample included 114 school psychology graduate students in their second, third, and fourth year of training. No significant differences were found among these three groups.

All analyses were conducted using SPSS, and all data were analyzed at the item level. We used descriptive analyses to examine students' perceptions of the extent to which school psychology graduate programs (a) focused on different areas of human diversity in their training programs, (b) explicitly taught the 16 basic multicultural competencies proposed by Vieten et al. (2016), (c) equipped graduate students with the knowledge and skills for employing the 12 advanced practice competencies proposed by Vogel et al. (2013), and (d) utilized different methods of learning to prepare students to address religious/spiritual diversity in their professional work. We examined the extent to which students perceived their training programs as focusing on religious/ spiritual diversity relative to other areas of diversity (e.g., race/ethnicity) using a one-way ANOVA with pairwise comparisons.

\section{Results}

\section{Diversity Foci in School Psychology Program}

Mean ratings reflecting the extent to which school psychology graduate students perceived their programs as addressing each area of human diversity ranged from $2.88(S D=1.1)$ to $4.22(S D=1.0)$. The areas of diversity with the lowest and highest ratings included religious/spiritual diversity and disability diversity, respectively. Consequently, students perceived their programs as significantly focusing on religious/ spiritual diversity to a lesser degree compared to all areas of human diversity (see Table 2). The majority of the intercorrelations between the seven variables were statistically significant $(p<0.01)$ and ranged in magnitude from small to large ( $r=0.22$ to 0.78 ). The results of the pairwise comparisons indicated that graduate students reported significantly higher scores for all areas of diversity compared to religious/ spiritual diversity: (a) gender diversity and religious/spiritual diversity, $\mathrm{F}(4,113)=4.34, p=0.003$; (b) racial/ethnic diversity and religious/spiritual diversity $\mathrm{F}(4,113)=2.65$, $p=0.04$; (c) sexual orientation diversity and religious/spiritual diversity, $\mathrm{F}(4,113)=4.08, p=0.004$; (d) age diversity and religious/spiritual diversity, $\mathrm{F}(4,113)=4.86, p=0.001$; (e) disability diversity and religious/spiritual diversity, F (4, 113 ) $=4.33, p=0.003$; and (f) socioeconomic diversity and religious/spiritual diversity, $\mathrm{F}(4,113)=5.02, p=0.001$.

\section{Perceived Training Relative to Religious/Spiritual Competencies}

With respect to the 16 basic religious and spiritual competencies, the mean ratings across the items ranged from $1.94(S D=1.0)$ to $2.33(S D=1.2)$. The items with the lowest and highest mean rating included, School Psychologists are aware of internal and external spiritual and/or religious resources and practices that research indicates may support psychological well-being and recovery from psychological disorders and School Psychologists view spirituality and religion as important aspects of human diversity, along with factors such as race, ethnicity, sexual orientation, socioeconomic status, disability, gender, and age, respectively. Regarding the 12 advanced religious and spiritual competencies, the mean ratings across the items ranged from 1.93 $(S D=1.0)$ to $2.82(S D=1.1)$. The item with the lowest mean rating included, Implementing religious/spiritual interventions in clinical work. The item with the highest mean ratings included, Considering religion/spirituality when determining if behavior is abnormal. Specific to the source of learning relative to religious/spiritual diversity, the mean 
Table 2 Bivariate associations between the perceived diversity foci in school psychology programs $(N=114)$

\begin{tabular}{llllllllll}
\hline Variable & $M$ & $S D$ & 1 & 2 & 3 & 4 & 5 & 6 & 7 \\
\hline 1. Gender Diversity & 3.34 & 1.0 & - & & & & & \\
2. Racial \& Ethnic Diversity & 3.87 & 1.1 & $0.59^{* * *}$ & - & & & & \\
3. Sexual Orientation Diversity & 3.46 & 1.1 & $0.78^{* * *}$ & $0.61^{* * *}$ & - & & & \\
4. Age Diversity & 3.15 & 1.1 & $0.35^{* * *}$ & $0.32^{* *}$ & $0.35^{* * *}$ & - & & \\
5. Disability Diversity & 4.22 & 1.1 & $0.33^{* * *}$ & $0.50^{* * *}$ & $0.24^{*}$ & $0.28^{* *}$ & - & & - \\
6. Socioeconomic Diversity & 3.99 & 1.0 & $0.32^{* *}$ & $0.51^{* * *}$ & $0.31^{* *}$ & $0.27 * *$ & $0.52^{* * *}$ & - \\
7. Religious/ Spiritual Diversity & 2.88 & 1.1 & $0.30^{* *}$ & $0.22^{*}$ & $0.28^{* *}$ & $0.31^{* *}$ & -0.01 & 0.11 & - \\
${ }^{*} p<.05, * * p<.01, * * * p<00.1$ & & & & & & & &
\end{tabular}

ratings across the items ranged from $2.11(S D=1.2)$ to 2.69 $(S D=1.1)$. The items with the lowest and highest mean rating included, Didactics, Seminars, and/or Grand Rounds and Practicum Experiences, respectively. See Tables 3, 4, to 5 for a summary of participants' responses.

\section{Discussion}

The purpose of this study was to examine school psychology graduate students' perceptions of their cross-cultural training relative to religious and spiritual diversity. Due to the dearth of attention to religious/spiritual diversity in the field (Parker et al., 2020), we specifically focused on these two areas of human diversity in the current study. Research focused on school psychology exclusively can add to the knowledge base in this area of inquiry, given that school psychology represents a unique field of practice (e.g., most school psychologists work in public school settings and hold an education specialist degree; Walcott \& Hyson, 2018). Our study expands upon the existing literature by underscoring school psychology students' perceived experiences.

Overall, participants reported that their graduate programs provided them with a basic understanding of why spirituality and religion are important aspects of human diversity, as evidenced by the competency with the highest rating on Vieten et al.'s (2016) set of basic competencies: School Psychologists view spirituality and religion as important aspects of human diversity, along with factors such as race, ethnicity, sexual orientation, socioeconomic status, disability, gender, and age. This finding may be expected, considering that the competency reflects the essence of ethical practice, wherein school psychologists are called to understand and respect differences based on one's religious identity (APA, 2017; NASP, 2020).

Nevertheless, student ratings on both sets of competencies suggest that participants received little training and preparation in their graduate programs to respond to religious/spiritual diversity in practice. Indeed, students in our study reported more preparation to address issues related to disability diversity, socioeconomic diversity, and racial/ ethnic diversity, and the least preparation to address issues related to religious/spiritual diversity. A similar finding was reported in McMinn et al.'s (2015) study, wherein respondents who attended clinical and counseling psychology programs indicated that their programs provided students less preparation to address issues related to religious/spiritual diversity and more preparation to address issues related to racial/ethnic diversity, socioeconomic diversity, and gender diversity. The finding related to racial/ethnic diversity and socioeconomic diversity in school psychology is unsurprising, given that issues focused on race/ethnicity and socioeconomic status appear to garner more attention in the professional school psychology literature (Parker et al., 2020). With respect to the emphasis on disability diversity, it is plausible that this finding can be explained by the role school psychologists typically assume in supporting youth with disabilities (NASP, 2020). In this regard, Castillo et al. (2012) found that school psychologists are likely to spend most of their time providing special education services in school settings, which may result in training programs prioritizing disability diversity as a necessary cross-cultural competence in response to historical trends in the field.

The extensive focus on disability diversity may also explain why the advanced competency item relative to graduate students being prepared to consider religion/spirituality when determining whether behavioral is abnormalreceived the highest rating. School psychology trainees are expected to have "knowledge bases for both psychology and education" (NASP, 2020, p. 19), which likely entails being prepared to understand "dysfunctional behavior or psychopathology" (APA, 2006). Such a focus may include school psychology trainees reviewing various disorders in the Diagthat impact children and adolescents. Several disorders in the DSM-5 allude to the importance of considering religion/ spirituality when practitioners make a diagnostic decision. For example, individuals with obsessive compulsive disorder may obsess over religious ideals (e.g., being fixated on salvation); and individuals may experience religious/spiritual experiences that are mistaken for hallucinations, in the absence of professionals conducting a culturally sensitive nostic and Statistical Manual of Mental Disorders (DSM-5) 
Table 3 Student ratings for Vieten et al.'s (2016) 16 basic competencies $(N=114)$

\begin{tabular}{|c|c|c|c|c|c|c|}
\hline Item & $M$ & $S D$ & $\begin{array}{l}\text { Have not received } \\
\text { explicit training in this } \\
\text { domain }\end{array}$ & $\begin{array}{l}\text { Have received a little bit } \\
\text { explicit training in this } \\
\text { domain }\end{array}$ & $\begin{array}{l}\text { Have received some } \\
\text { explicit training in this } \\
\text { domain }\end{array}$ & $\begin{array}{l}\text { Have received comprehen- } \\
\text { sive formal training in this } \\
\text { domain }\end{array}$ \\
\hline $\begin{array}{l}\text { 1. School Psychologists } \\
\text { demonstrate empathy, } \\
\text { respect, and appre- } \\
\text { ciation for clients (or } \\
\text { students) from diverse } \\
\text { spiritual, religious, or } \\
\text { secular backgrounds } \\
\text { and affiliations }\end{array}$ & 2.07 & 1.1 & $36.0 \%$ & $37.7 \%$ & $9.6 \%$ & $16.7 \%$ \\
\hline $\begin{array}{l}\text { 2. School Psychologists } \\
\text { view spirituality and } \\
\text { religion as important } \\
\text { aspects of human } \\
\text { diversity, along with } \\
\text { factors such as race, } \\
\text { ethnicity, sexual orien- } \\
\text { tation, socioeconomic } \\
\text { status, disability, } \\
\text { gender, and age }\end{array}$ & 2.33 & 1.2 & $30.7 \%$ & $29.8 \%$ & $14.9 \%$ & $24.6 \%$ \\
\hline $\begin{array}{l}\text { 3. School Psychologists } \\
\text { are aware of how their } \\
\text { own spiritual and/or } \\
\text { religious background } \\
\text { and beliefs may influ- } \\
\text { ence their critical } \\
\text { practice, and their atti- } \\
\text { tudes, perceptions and } \\
\text { assumptions about the } \\
\text { nature of psychological } \\
\text { processes }\end{array}$ & 2.25 & 1.0 & $23.7 \%$ & $45.6 \%$ & $13.2 \%$ & $17.5 \%$ \\
\hline $\begin{array}{l}\text { 4. School Psycholo- } \\
\text { gists know that many } \\
\text { diverse forms of spir- } \\
\text { ituality and/or religion } \\
\text { exist and explore spir- } \\
\text { itual and/or religious } \\
\text { beliefs, communities } \\
\text { and practices that are } \\
\text { important to their } \\
\text { clients (or students) }\end{array}$ & 2.27 & 1.0 & $27.2 \%$ & $35.1 \%$ & $21.1 \%$ & $16.7 \%$ \\
\hline $\begin{array}{l}\text { 5. School Psycholo- } \\
\text { gists can describe } \\
\text { how spirituality and } \\
\text { religion can be viewed } \\
\text { as overlapping, yet } \\
\text { distinct, constructs }\end{array}$ & 2.04 & 1.0 & $40.4 \%$ & $19.3 \%$ & $36.0 \%$ & $4.4 \%$ \\
\hline $\begin{array}{l}\text { 6. School Psychologists } \\
\text { understand that clients } \\
\text { (or students) may have } \\
\text { experiences that are } \\
\text { consistent with their } \\
\text { spirituality or religion, } \\
\text { yet may be difficult } \\
\text { to differentiate from } \\
\text { psychopathological } \\
\text { symptoms }\end{array}$ & 2.08 & 1.0 & $40.4 \%$ & $19.3 \%$ & $32.5 \%$ & $7.9 \%$ \\
\hline
\end{tabular}


Table 3 (continued)

\begin{tabular}{|c|c|c|c|c|c|c|}
\hline Item & $M$ & $S D$ & $\begin{array}{l}\text { Have not received } \\
\text { explicit training in this } \\
\text { domain }\end{array}$ & $\begin{array}{l}\text { Have received a little bit } \\
\text { explicit training in this } \\
\text { domain }\end{array}$ & $\begin{array}{l}\text { Have received some } \\
\text { explicit training in this } \\
\text { domain }\end{array}$ & $\begin{array}{l}\text { Have received comprehen- } \\
\text { sive formal training in this } \\
\text { domain }\end{array}$ \\
\hline $\begin{array}{l}\text { 7. School Psychologists } \\
\text { recognize that spir- } \\
\text { itual and/or religious } \\
\text { beliefs, practices and } \\
\text { experiences develop } \\
\text { and change over the } \\
\text { lifespan }\end{array}$ & 2.11 & 1.0 & $35.1 \%$ & $26.3 \%$ & $30.7 \%$ & $7.9 \%$ \\
\hline $\begin{array}{l}\text { 8. School Psychologists } \\
\text { are aware of internal } \\
\text { and external spir- } \\
\text { itual and/or religious } \\
\text { resources and practices } \\
\text { that research indicates } \\
\text { may support psycho- } \\
\text { logical well-being and } \\
\text { recovery from psycho- } \\
\text { logical disorders }\end{array}$ & 1.94 & 1.0 & $43.9 \%$ & $22.8 \%$ & $28.9 \%$ & $4.4 \%$ \\
\hline $\begin{array}{l}\text { 9. School Psychologists } \\
\text { can identify spiritual } \\
\text { and religious experi- } \\
\text { ences, practices and } \\
\text { beliefs that may have } \\
\text { potential to negatively } \\
\text { impact psychological } \\
\text { health }\end{array}$ & 2.13 & 0.9 & $36.8 \%$ & $14.9 \%$ & $46.5 \%$ & $1.8 \%$ \\
\hline $\begin{array}{l}\text { 10. School Psychologists } \\
\text { can identify legal and } \\
\text { ethical issues related to } \\
\text { spirituality and/or reli- } \\
\text { gion that may surface } \\
\text { when working with } \\
\text { clients (or students) }\end{array}$ & 1.95 & 1.0 & $44.7 \%$ & $24.6 \%$ & $21.9 \%$ & $8.8 \%$ \\
\hline $\begin{array}{l}\text { 11. School Psychologists } \\
\text { are able to conduct } \\
\text { empathic and effective } \\
\text { psychotherapy with } \\
\text { clients (or students) } \\
\text { from diverse spiritual } \\
\text { and/or religious back- } \\
\text { grounds, affiliations } \\
\text { and levels of involve- } \\
\text { ment }\end{array}$ & 2.21 & 1.0 & $28.9 \%$ & $36.8 \%$ & $18.4 \%$ & $15.8 \%$ \\
\hline $\begin{array}{l}\text { 12. School Psychologists } \\
\text { inquire about spiritual } \\
\text { and/or religious back- } \\
\text { ground, experience, } \\
\text { practices, attitudes and } \\
\text { beliefs as a standard } \\
\text { part of understanding } \\
\text { a client's (or student's) } \\
\text { history }\end{array}$ & 2.11 & 1.0 & $36.8 \%$ & $25.4 \%$ & $28.1 \%$ & $9.6 \%$ \\
\hline $\begin{array}{l}\text { 13. School Psycholo- } \\
\text { gists help clients (or } \\
\text { students) explore and } \\
\text { access their spir- } \\
\text { itual and/or religious } \\
\text { strengths and resources }\end{array}$ & 2.32 & 1.0 & $29.8 \%$ & $13.2 \%$ & $51.8 \%$ & $5.3 \%$ \\
\hline
\end{tabular}


Table 3 (continued)

\begin{tabular}{|c|c|c|c|c|c|c|}
\hline Item & $M$ & $S D$ & $\begin{array}{l}\text { Have not received } \\
\text { explicit training in this } \\
\text { domain }\end{array}$ & $\begin{array}{l}\text { Have received a little bit } \\
\text { explicit training in this } \\
\text { domain }\end{array}$ & $\begin{array}{l}\text { Have received some } \\
\text { explicit training in this } \\
\text { domain }\end{array}$ & $\begin{array}{l}\text { Have received comprehen- } \\
\text { sive formal training in this } \\
\text { domain }\end{array}$ \\
\hline $\begin{array}{l}\text { 14. School Psycholo- } \\
\text { gists can identify and } \\
\text { address spiritual and/ } \\
\text { or religious problems } \\
\text { in their practice and } \\
\text { make referrals when } \\
\text { necessary }\end{array}$ & 2.21 & 1.0 & $35.1 \%$ & $11.4 \%$ & $50.9 \%$ & $2.6 \%$ \\
\hline $\begin{array}{l}\text { 15. School Psycholo- } \\
\text { gists stay abreast of } \\
\text { research and profes- } \\
\text { sional developments } \\
\text { regarding spirituality } \\
\text { and religion spe- } \\
\text { cifically related to their } \\
\text { practice and engage in } \\
\text { ongoing assessment of } \\
\text { their own spiritual and } \\
\text { religious competence }\end{array}$ & 2.29 & 0.9 & $29.8 \%$ & $14.9 \%$ & $51.8 \%$ & $3.5 \%$ \\
\hline $\begin{array}{l}\text { 16. School Psychologists } \\
\text { recognize the limits of } \\
\text { their qualifications and } \\
\text { competence in the spir- } \\
\text { itual and/or religious } \\
\text { domains, including any } \\
\text { responses to clients' } \\
\text { (or students') spiritual- } \\
\text { ity and/or religion } \\
\text { that may interfere } \\
\text { with clinical practice, } \\
\text { so that they (a) seek } \\
\text { consultation from } \\
\text { and collaborate with } \\
\text { qualified clinicians } \\
\text { or spiritual/religious } \\
\text { source (e.g., priests, } \\
\text { pastors, rabbis, imam, } \\
\text { spiritual teachers, } \\
\text { etc.), (b) seek further } \\
\text { training and education } \\
\text { and/or (c) refer clients } \\
\text { (or students) to more } \\
\text { qualified individuals } \\
\text { and resources }\end{array}$ & 2.18 & 1.1 & $33.3 \%$ & $30.7 \%$ & $20.2 \%$ & $15.8 \%$ \\
\hline
\end{tabular}

diagnostic assessment. As such, it is plausible that graduate students are exposed to content highlighting the intersection of religion, spirituality, and abnormal behavior within the context of learning about psychopathology and behavioral disorders.

In contrast, participants indicated that they received little training in the areas of (a) understanding internal and external spiritual and/or religious resources and practices that research indicates may support psychological well-being and recovery from psychological disorders and (b) implementing religious/spiritual interventions in clinical work. This finding supports a critical point emphasized by Jones
(2014), with respect to school psychologists implementing culturally responsive interventions in practice. Culturally responsive interventions should (a) build upon families' cultural strengths (including their religious and spiritual belief system) and (b) integrate such in the intervention plan, if it is relevant for the client served. However, school psychologists have historically ignored religion and spirituality within the context of intervention service delivery, reflecting a limitation in their delivery of culturally responsive supports (Jones, 2014).

The lack of training in integrating religion and spirituality in interventions may be attributed to trainers' response to 
Table 4 Student ratings for Vogel et al.'s (2013) 12 advanced competencies $(N=114)$

\begin{tabular}{|c|c|c|c|c|c|c|c|}
\hline Item & $M$ & $S D$ & Strongly Disagree & Disagree & Neutral & Agree & Strongly Agree \\
\hline $\begin{array}{l}\text { 1. Ethical guidelines and professional standards for religion/spir- } \\
\text { ituality }\end{array}$ & 2.81 & 1.1 & $8.8 \%$ & $35.1 \%$ & $26.3 \%$ & $26.3 \%$ & $3.5 \%$ \\
\hline $\begin{array}{l}\text { 2. Case conceptualization in light of clients' (or students') reli- } \\
\text { gious/spiritual values }\end{array}$ & 2.72 & 1.1 & $15.8 \%$ & $30.7 \%$ & $23.7 \%$ & $25.4 \%$ & $4.4 \%$ \\
\hline $\begin{array}{l}\text { 3. Assessment methods that consider } \\
\text { religion/spirituality in clients' (or students') lives }\end{array}$ & 2.26 & 1.1 & $27.2 \%$ & $43.0 \%$ & $9.6 \%$ & $16.7 \%$ & $3.5 \%$ \\
\hline 4. Implementing religious/spiritual interventions in clinical work & 1.93 & 1.0 & $38.6 \%$ & $44.7 \%$ & $4.4 \%$ & $9.6 \%$ & $2.6 \%$ \\
\hline $\begin{array}{l}\text { 5. Countertransference issues with religiously/spiritually commit- } \\
\text { ted clients (or students) }\end{array}$ & 2.39 & 1.2 & $28.9 \%$ & $33.3 \%$ & $11.4 \%$ & $21.9 \%$ & $4.4 \%$ \\
\hline $\begin{array}{l}\text { 6. Self-reflective practices during work with religious/spiritual } \\
\text { clients (or students) }\end{array}$ & 2.68 & 1.2 & $21.1 \%$ & $25.4 \%$ & $22.8 \%$ & $25.4 \%$ & $5.3 \%$ \\
\hline $\begin{array}{l}\text { 7. Conducting research that is sensitive to religious/spiritual } \\
\text { diversity }\end{array}$ & 2.45 & 1.1 & $21.9 \%$ & $38.6 \%$ & $14.9 \%$ & $21.9 \%$ & $2.6 \%$ \\
\hline 8. Understanding the major world religions/spiritualities & 2.32 & 1.1 & $20.2 \%$ & $46.6 \%$ & $12.3 \%$ & $17.5 \%$ & $3.5 \%$ \\
\hline 9. Consultation skills related to religious/spiritual diversity & 2.55 & 1.2 & $22.8 \%$ & $31.6 \%$ & $16.7 \%$ & $25.4 \%$ & $3.5 \%$ \\
\hline 10. Interdisciplinary collaboration with religious/spiritual leaders & 2.32 & 1.2 & $28.9 \%$ & $37.7 \%$ & $9.6 \%$ & $20.2 \%$ & $3.5 \%$ \\
\hline $\begin{array}{l}\text { 11. Considering religion/spirituality when determining if behavior } \\
\text { is abnormal }\end{array}$ & 2.82 & 1.1 & $14.0 \%$ & $22.8 \%$ & $34.2 \%$ & $22.8 \%$ & $6.1 \%$ \\
\hline $\begin{array}{l}\text { 12. Views of personhood from the perspectives of major religions/ } \\
\text { spiritualities }\end{array}$ & 2.67 & 1.2 & $22.8 \%$ & $25.4 \%$ & $17.5 \%$ & $30.7 \%$ & $3.5 \%$ \\
\hline
\end{tabular}

Note. Strongly Disagree and Disagree suggest that students perceived they did not learn about religious/spiritual diversity in the practice domain; Neutral suggests that students neither disagreed or agreed with the idea of learning about religious/spiritual diversity in the practice domain; and Agree and Strongly Agree suggest that students perceived they learned about religious/spiritual diversity in the practice domain

Table 5 Source of religious/spiritual diversity learning in graduate programs $(N=114)$

\begin{tabular}{|c|c|c|c|c|c|c|c|}
\hline Item & $M$ & $S D$ & Never & Rarely & Sometimes & Often & Always \\
\hline Coursework (e.g., assigned readings, class projects) & 2.52 & 1.1 & $18.4 \%$ & $32.5 \%$ & $32.5 \%$ & $11.4 \%$ & $5.3 \%$ \\
\hline Advisers and Mentors & 2.41 & 1.2 & $25.4 \%$ & $35.1 \%$ & $19.3 \%$ & $13.2 \%$ & $7.0 \%$ \\
\hline Practicum Experiences (e.g., supervision, client contact) & 2.69 & 1.1 & $14.9 \%$ & $28.9 \%$ & $37.7 \%$ & $10.5 \%$ & $7.9 \%$ \\
\hline Peer Interaction (e.g., student-led dialogue, peer feedback) & 2.28 & 1.1 & $13.2 \%$ & $23.7 \%$ & $38.6 \%$ & $16.7 \%$ & $7.9 \%$ \\
\hline Didactics, Seminars, and/or Grand Rounds & 2.11 & 1.2 & $34.2 \%$ & $35.1 \%$ & $19.3 \%$ & $8.8 \%$ & $2.6 \%$ \\
\hline Extracurricular Pursuits (e.g., conferences, voluntary readings) & 2.60 & 1.1 & $15.8 \%$ & $31.6 \%$ & $35.1 \%$ & $12.3 \%$ & $5.3 \%$ \\
\hline Research (e.g., peer-reviewed articles) & 2.39 & 1.1 & $22.8 \%$ & $35.1 \%$ & $24.6 \%$ & $14.9 \%$ & $2.6 \%$ \\
\hline
\end{tabular}

Note. Never suggests that students perceived they did not learn about religious/spiritual diversity through the listed source of learning; Rarely, Sometimes, and Often suggest that students perceived they learned about religious/spiritual diversity through the listed source of learning to some extent; and Always suggests that students perceived they learned about religious/spiritual diversity through the listed source of learning

school psychologists' traditional role in conducting evaluations more frequently than providing direct intervention services (Castillo et al., 2012). The limited attention to religion and spirituality within the context of interventions may also be driven by the context in which school psychologists traditionally work_-public schools (Walcott \& Hyson, 2018). Public school-based employees may be hesitant to respond to students' religious and spiritual identities due concerns about the separation of church and state (Magaldi-Dopman \& Park-Taylor, 2014). As programs who are responsible for preparing public school employees, school psychology faculty may perceive that extensive preparation for integrating religious and spiritual factors in intervention plans may not be useful for school-based employees. More research is needed to examine these assumptions to understand school psychology program faculty's perceptions of addressing religious and spiritual diversity in their training programs.

Like these results, among a large sample of general psychologists, approximately $70 \%$ of participants in Vieten et al.'s (2016) study reported that they received little or no explicit training in various domains religious/spiritual diversity competencies. Together, findings from our study and previous research demonstrate limited attention to religious and spiritual diversity in health service psychology 
programs, despite professional practice standards emphasizing the relevance of all areas of human diversity (APA, 2017; NASP, 2020). Still, as counseling and clinical psychology students in McMinn et al.'s (2015) study reported higher ratings relative to the 12 advanced competencies (range, 2.2-3.1) compared to our sample of school psychology students (range, 2.1-2.8), school psychology programs may be particularly lacking attention to these core aspects of human diversity.

\section{Limitations and Future Research}

The findings of this study should be interpreted within the context of its limitations. First, we collected data via an online self-report survey. This may have resulted in response and social desirability biases, phenomena that are likely to be observed on self-report competence scales (Constantine, 2000; Constantine \& Ladany, 2000). We also did not survey school psychology program faculty to understand their perceptions of the training they provide. Future research can address this limitation by surveying faculty and students simultaneously to compare their responses and increase the field's understanding of the extent to which school psychology programs address issues related to religious/spiritual diversity. We recruited research participants on a voluntary basis through e-mail correspondence with the program trainers; and abrupt changes due to COVID-19 interfered with our capacity to recruit additional participants across the country. Due to these limitations, the results may not represent the perception of trainees across all school psychology programs in the US. Our approach to participant recruitment also may have influenced their response to survey items (e.g., most of our participants identified as Christian) and limit the generalizability of the results due to the lack of random sampling. Therefore, additional studies could employ more rigorous research methods to address these limitations and build upon this research.

Our team did not make significant changes to the two set of competencies, other than referencing the practice of school psychology as opposed to the practice of psychology in general. However, researchers have yet to complete a comprehensive vetting process to solicit multiple perspectives about the relevance of both set of competencies in the field of school psychology. Although school psychology practitioners who participated in Parker's (2019) study viewed Vieten et al.'s (2016) competencies as important for the field, future research can gain input from cross-cultural experts and school psychology practitioners to establish the social validity of both set of competencies in the field of school psychology.

\section{Implications for School Psychology Training}

School psychology program faculty can utilize the results of this exploratory study to reflect on the extent to which they are preparing graduate students to address the areas of religious/spiritual diversity in their professional work, as emphasized by practice and ethical standards put forth by APA (2017) and NASP (2020). Because school stakeholders "do not just leave their religious beliefs at home," (Parker \& Hanson, 2019, p. 9), the field of school psychology would be remiss if graduate students are inadequately prepared to navigate religious and spiritual diversity as emerging professionals. Unfortunately, respondents in the current study reported receiving little preparation to address these two aspects of human diversity through formal coursework, even though formal coursework and field experiences are critical for preparing culturally responsive practitioners (Jones et al., 2013; Newell et al., 2010).

School psychology faculty should strive to embed content focused on religious and spiritual diversity in their classes/curricula sequence if such efforts are not employed. To equip trainees with the attitudes, knowledge, and skills they need to address issues related to religious and spiritual diversity, cross-cultural competence training should begin with encouraging graduate students to (a) develop an awareness of their own religious/spiritual identity, (b) appreciate that PK-12 students, families and teachers may have different religious/spiritual beliefs, and (c) understand how their own religious/spiritual identity and that of key stakeholders may impact the school psychologist's perceptions of and professional interactions with the individuals they serve (Miranda, 2014; Vieten et al., 2016).

Regarding the latter, for example, it is important to emphasize that school psychologists should not disregard clients' religious and spiritual beliefs based on the practitioners' own worldviews. An example of such was provided by a school psychologist who participated in the study conducted by Parker and Hanson (2019), suggesting that practitioners' personal beliefs can disrupt the relationship between the school psychologist and the client:

"Being able to pray as a family...[is] going to be your primary [approach]...I support you with that. That's great. What other things can we add onto that?" And so, I try to be respectful because it's very off putting if someone comes in and says, "Well no but that's not [effective], praying is not going to keep your child safe. Praying is not going to keep your child from doing XYZ." (p. 8)

It is also incumbent upon graduate trainers to encourage school psychology trainees to (a) be aware of how their own religious and spiritual belief system may interfere with 
their capacity to serve students/families with different belief systems or other social identities, and (b) make necessary steps to rectify personal barriers to providing non-biased, culturally responsive services (e.g., gaining more exposure to diverse groups, considering transitioning to another profession). For example, mental health providers refusing to serve LGBTQ + clients due to the providers' religious/spiritual belief system is unethical and potentially illegal (see the following two legal cases: Bruff v. North Mississipi Health Services, Inc. [2001] and Ward v. Willbanks [2010]).

Moreover, cross-cultural training relative to religious and spiritual diversity (and other aspects of diversity for that matter) should not be limited to a single diversity course (Newell et al., 2010). Just as Vogel's advanced religious/ spiritual practice competencies focus on the importance of preparing graduate students to apply their knowledge relative to religious/spiritual diversity across multiple aspects of professional psychological service, school psychologists should be prepared to provide culturally responsive services with religiously/spiritually diverse clients in various domains of professional practice (Rogers \& Lopez, 2002): assessment, intervention, and consultation. Assessment courses, for example, could help school psychology trainees understand how to inquire about students' and families' religious/spiritual beliefs (Jones, 2014) when seeking to conceptualize the client's needs.

Intervention courses could review how school psychologists may adapt existing interventions to be responsive to students' and families' religious/spiritual worldviews, as emphasized in the professional literature (e.g., Haboush, 2007, 2010); Jerome, 2011; Suzuki et al., 2006; Tynan et al., 2015). An example of such may include affirming families' decisions to utilize religious/spiritualbased practices as a source of coping (e.g., Parker \& Hanson, 2019). As religious and spiritual issues also may arise within the context of school-based consultation (Parker \& Hanson, 2019), school psychology trainees should be prepared to demonstrate sensitivity to both clients' and consultees' religious/spiritual beliefs. Because student advocacy is a critical aspect of school psychologists' professional work, trainees also should be equipped to advocate for clients who are negatively impacted by a school and community climate that utilize religious rhetoric to ostracize and marginalize other youth (i.e., religiously/spiritually minoritized youth and/or LGBTQ + youth; Atwal \& Wang, 2019; Dupper et al., 2015; Goforth et al., 2017a, 2017b; Haboush, 2010); Newman et al., 2018; Sulkowski et al., 2014).

We recognize that in-depth training around religious and spiritual diversity may be impossible for school psychology programs; this is especially true for specialist-level students who only receive two years of formal coursework before they go on to internship. School psychology faculty can create a resource bank for students to access on their own time through self-study and personal initiation because learning in this area of practice can occur through multiple modalities (Plante, 2014). Based on Plante's (2014) recommendations and the core methods of learning Vogel et al.'s (2013) study highlight, faculty can provide students with resources to help them understand different religious/spiritual groups, including how they may perceive educational and psychological services. Additional literature may cover a range of related topics, such as when and how to partner with various religious/spiritual organizations when issues arise in practice. Students also can be informed about conferences and other professional development opportunities to expand their awareness, knowledge, and skills with respect to culturally responsive practice. To foster students' capacity to collaborate with individuals from diverse religious/spiritual backgrounds, faculty could alert students to relevant, public community events for field-based learning. Faculty also can inform students of professional interest groups and invite guest speakers to share insight about this topic to help students build their professional network related to this area of practice.

Finally, school psychology faculty may wish to have focused discussions about the implications of responding to religious/spiritual diversity as mental health providers who are also required to adhere to the separation of church in their role as public-school employees. Case law supports the idea that school-based employees should not force students to engage in religious/spiritual practices or adopt specific religious/spiritual practices at the school level (e.g., Doe v. Elmbrook Sch. Dist.-687 F.3d 840 [7th Cir. 2012]; Santa Fe Independent School District v. Doe, 530 U.S. 290 [2000]; Stone v. Graham, 449 U.S. 39 [1980]). However, limited guidance has been published in the professional literature regarding how school-based mental health providers should respond to students/families who allude to their religious/ spiritual beliefs when receiving counseling or psychological services. Drawing from prior work focused on this topic in the field of school counseling, trainers could emphasize that school mental health providers may have some latitude to address students' spiritual and religious worldviews if practitioners do not impose their spiritual/religious beliefs on students/families and advocate for the adoption of one religion over another (Wolf, 2004). School psychology trainers may also wish to review proposed spiritual and religious competencies Kimbel and Schellenberg (2013) developed for school counselors to guide program and classroom conversations about this topic. Ultimately, it may be in their best interest to encourage graduate students to consult with supervisors or district attorneys for guidance and support to make a decision that is most appropriate for their work setting. 


\section{Conclusion}

Religion and spirituality are core aspects of an individual's cultural background, alongside other markers of one's cultural identity. National survey data (Lyons, 2004; Pew Research Center, 2019; Twenge et al., 2015) unequivocally show that students, families, and educators with whom school psychologists serve will likely represent diverse religious/spiritual identities that can permeate within the school and clinical setting. Considering that religion and spirituality can influence individuals' beliefs, values, behaviors, and experiences, including how individuals marginalize other human beings, it is incumbent upon school psychology faculty to acknowledge and respond to this reality. As a field that proclaims to be champions of multiculturalism, culturally responsive practice, and social justice, we cannot continue to minimize certain domains of human diversity. To this end, school psychology programs are well-positioned to build a foundation for emerging practitioners by equipping them with the knowledge they need to respond to religious and spiritual diversity before beginning practice.

\section{Declarations}

Ethics Approval This study was approved by the William \& Mary Institutional Review Board in 2019. We obtained informed consent from all participants and all data are deidentified.

Conflict of Interest The authors declare no competing interests.

\section{References}

Abdel-Khalek, A. M. (2007). Religiosity, happiness, health, and psychopathology in a probability sample of Muslim adolescents. Mental Health, Religion and Culture, 10(6), 571-583. https:// doi.org/10.1080/13674670601034547

American Psychological Association. (2006). Guidelines and Principles for Accreditation of Programs in Professional Psychology $(G \& P)$. Retreived June 2, 2021 from https://doi.org/http://www. apa.org/ed/accreditation/about/policies/guiding-principles.pdf

American Psychological Association. (2017). Ethical principles of psychologists and code of conduct. Retrieved from https://www. apa.org/ethics/code

Atwal, K., \& Wang, C. (2019). Religious head covering, being perceived as foreigners, victimization, and adjustment among Sikh American adolescents. School Psychology, 34, 233-243. https:// doi.org/https://psycnet.apa.org/doi/10.1037/spq0000301

Bruff v. North Mississipi Health Services, Inc, No. 99-60175 (5th Cir. Mar. 28, 2001). https://caselaw.findlaw.com/us-5th-circuit/14534 88.html

Castillo, J. M., Curtis, M. J., \& Gelley, C. (2012). School psychology 2010-Part 2: School psychologists' professional practices and implications for the field. Communiqué, 40(8), 4-6

Constantine, M. G. (2000). Social desirability attitudes, sex, and affective and cognitive empathy as predictors of self-reported multicultural counseling competence. The Counseling Psychologist, 28(6), 857-872. https://doi.org/10.1177/0011000000286008

Constantine, M. G., \& Ladany, N. (2000). Self-report multicultural counseling competence scales: Their relation to social desirability attitudes and multicultural case conceptualization ability. Journal of Counseling Psychology, 47(2), 155-164. https://doi.org/https:// psycnet.apa.org/doi/10.1037/0022-0167.47.2.155

Cotton, S., Larkin, E., Hoopes, A., Cromer, B. A., \& Rosenthal, S. L. (2005). The impact of adolescent spirituality on depressive symptoms and health risk behaviors. Journal of Adolescent Health, 36(6), 529. https://doi.org/10.1016/j.jadohealth.2004.07.017

Dill, L. J. (2017). "Wearing my spiritual jacket": The role of spirituality as a coping mechanism among African American youth. Health Education \& Behavior, 44(5), 696-704. https://doi.org/10.1177/ 1090198117729398

Doe v. Elmbrook Sch. Dist., 687 F.3d 840, 282 Ed. Law Rep. 829 (7th Cir. 2012). https://www.becketlaw.org/case/elmbrook-school-distr ict-v-doe/

Dupper, D. R., Forrest-Bank, S., \& Lowry-Carusillo, A. (2015). Experiences of religious minorities in public school settings: Findings from focus groups involving Muslim, Jewish, Catholic, and Unitarian Universalist youths. Children \& Schools, 37(1), 37-45. https://doi.org/10.1093/cs/cdu029

Goforth, A. N., Pham, A. V., Chun, H., Castro-Olivo, S. M., \& Yosai, E. R. (2016). Association of acculturative stress, Islamic practices, and internalizing symptoms among Arab American adolescents. School Psychology Quarterly, 31(2), 198-212. https://doi.org/10. 1037/spq0000135

Goforth, A. N., Nichols, L. M., Stanick, C. F., Shindorf, Z. R., \& Holter, O. (2017a). School-based considerations for supporting Arab American youths' mental health. Contemporary School Psychology, 21(3), 191-200. https://doi.org/10.1007/s40688-016-0117-7

Goforth, A. N., Yosai, E. R., Brown, J. A., \& Shindorf, Z. R. (2017b). A multi-method inquiry of the practice and context of rural school psychology. Contemporary School Psychology, 21(1), 58-70

Haboush, K. L. (2007). Working with Arab American families: Culturally competent practice for school psychologists. Psychology in the Schools, 44(2), 183-198. https://doi.org/10.1002/ pits. 20215

Hardy, S. A., \& Raffaelli, M. (2003). Adolescent religiosity and sexuality: An investigation of reciprocal influences. Journal of Adolescence, 26(6), 731-739. https://doi.org/10.1016/j.adole scence.2003.09.003

Haboush, K. L. (2010). Training school psychologists to intervene with Arab American students. Trainers' Forum, 29(1), 38-45

Hodge, D. R, Limb, G. E., \& Cross, T. L. (2009). Moving from Colonization toward balance and harmony: A Native American perspective on wellness. Social Work, 54(3), 211-219. https:// doi.org/https://www.jstor.org/stable/23719497

Jerome, A. (2011). Comforting children and families who grieve: Incorporating spiritual support. School Psychology International, 32(2), 194-209. https://doi.org/10.1177/0143034311 400829

Jones, J. (2014). Best practices in providing culturally responsive inter-ventions. In P. L. Harrison \& A. Thomas (Eds.), Best practices in school psychology: Foundations (pp. 49-60). Bethesda: National Association of School Psychologists

Jones, J. M., Sander, J. B., \& Booker, K. W. (2013). Multicultural competency building: Practical solutions for training and evaluating student progress. Training and Education in Professional Psychology, 7(1), 12-22. https://doi.org/https://psycnet.apa.org/ doi/10.1037/a0030880

Kim, S., \& Esquivel, G. B. (2011). Adolescent spirituality and resilience: Theory, research, and educational practices. Psychology in the Schools, 48(7), 755-765. https://doi.org/10.1002/pits.20582 
Kimbel, T. M., \& Schellenberg, R. (2013). Meeting the holistic needs of students: A proposal for spiritual and religious competencies for school counselors. Professional School Counseling, 17(1), 76-85. https://doi.org/10.1177/2156759X0001700110

Kouyoumdjian, H., Zamboanga, B. L., \& Hansen, D. J. (2003). Barriers to community mental health services for Latinos: Treatment considerations. Clinical Psychology: Science and Practice, 10(4), 394-422. https://doi.org/10.1093/clipsy.bpg041

Lyons, L. (2004). Today's teens keeping the faith. Gallup. Retrieved from https://doi.org/https://news.gallup.com/poll/12928/todaysteens-keeping-faith.aspx

Magaldi-Dopman, D., \& Park-Taylor, J. (2014). Integration amidst separation: Religion, urban education, and the first amendment. The Urban Review, 46(1), 47-62. https://doi.org/10.1007/ s11256-013-0245-6

McMinn, M. R., Vogel, M. J., Hall, M. E. L., Abernethy, A. D., Birch, R., Galuza, T., ... \& Putman, K. (2015). Religious and spiritual diversity training in clinical psychology doctoral programs: Do explicitly Christian programs differ from other programs?. Journal of Psychology and Theology, 43(3), 155-164. https://doi.org/ $10.1177 / 009164711504300301$

Miranda, A. H. (2014). Best practices in increasing cross-cultural competency. In P. L. Harrison \& A. Thomas (Eds.), Best practices in school psychology: Foundations (pp. 9-20). National Association of School Psychologists.

National Association of School Psychologists. (2020). The Professional Standards of the National Association of School Psychologists. Author

Newell, M., Nastasi, B., Hatzichristou, C., Jones, J., Schanding Jr, G., \& Yetter, G. (2010). Evidence on multicultural training in school psychology: Recommendations for future directions. School Psychology Quarterly, 25(4), 249-278. https://doi.org/https://psycn et.apa.org/doi/10.1037/a0021542

Newman, P. A., Fantus, S., Woodford, M. R., \& Rwigema, M.-J. (2018). "Pray that God will change you": The religious social ecology of bias-based bullying targeting sexual and gender minority youth-A qualitative study of service providers and educators. Journal of Adolescent Research, 33(5), 523-548. https://doi.org/10.1177/0743558417712013

Park, H. S., \& Bonner, P. (2008). Family religious involvement, parenting practices and academic performance in adolescents. School Psychology International, 29(3), 348-362. https://doi. org/10.1177/0143034308093677

Parker, J. S. (2019). Spiritual and religious multicultural practice competencies: A partial replication study with school psychologists. School Psychology Forum, 13(1), 53-73

Parker, J. S., \& Hanson, P. (2019). School stakeholders do not "just leave their religious beliefs at home": An exploratory study of school psychologists' professional experience. International Journal of School \& Educational Psychology, 9(1), 88-100. https://doi. org/10.1080/21683603.2019.1666441

Parker, J. S., Fulmore, K., Schulze, M., Marano, L., Manderfield, C., \& Anderson, J. (2020). Spirituality and religiosity as diversity topics in school psychology publication: A content analysis of school psychology journals. Contemporary School Psychology. Advance online publication. https://doi.org/10.1007/s40688-019-00271-y

Pew Research Center. (2019). Religious landscape study. Retrieved from https://doi.org/http://www.pewforum.org/religious-lands cape-study/

Plante, T. G. (2014). Four steps to improve religious/spiritual cultural competence in professional psychology. Spirituality in Clinical Practice, 1(4), 288-292. https://doi.org/10.1037/scp0000047

Rogers, M. R., \& Lopez, E. C. (2002). Identifying critical cross-cultural school psychology competencies. Journal of School Psychology, 40(2), 115-141. https://doi.org/10.1016/S0022-4405(02)00093-6
Santa Fe Independent School District v. Doe, 530 U.S. 290 (2000). https://www.britannica.com/event/Santa-Fe-Independent-SchoolDistrict-v-Doe

Schafer, R. M., Handal, P. J., Brawer, P. A., \& Ubinger, M. (2011). Training and education in religion/spirituality within APAaccredited clinical psychology programs: 8 years later. Journal of Religion and Health, 50(2), 232-239. https://doi.org/10.1007/ s10943-009-9272-8

Sinha, J. W., Cnaan, R. A., \& Gelles, R. J. (2007). Adolescent risk behaviors and religion: Findings from a national study. Journal of Adolescence, 30, 231-249. https://doi.org/10.1016/j.adolescence. 2006.02.005

Stone v. Graham, 449 U.S. 39 (1980). https://www.mtsu.edu/firstamend ment/article/696/stone-v-graham

Sue, D. W., Arredondo, P., \& McDavis, R. J. (1992). Multicultural counseling competencies and standards: A call to the profession. Journal of Multicultural Counseling and Development, 20(2), 64-88. https://doi.org/10.1002/j.1556-6676.1992.tb01642.x

Sulkowski, M. L., Bauman, S., Wright, S., Nixon, C., \& Davis, S. (2014). Peer victimization in youth from immigrant and nonimmigrant US families. School Psychology International, 35(6), 649-669. https://doi.org/10.1177/0143034314554968

Suzuki, L. A., Alexander, C. M., Lin, P. Y., \& Duffy, K. M. (2006). Psychopathology in the schools: Multicultural factors that impact assessment and intervention. Psychology in the Schools, 43(4), 429-438. https://doi.org/10.1002/pits.20157

Taylor, R. J., Ellison, C. G., Chatters, L. M., Levin, J. S., \& Lincoln, K. D. (2000). Mental health services in faith communities: The role of clergy in black churches. Social Work, 45(1), 73-87.

Twenge, J. M., Exline, J. J., Grubbs, J. B., Sastry, R., \& Campbell, W. K. (2015). Generational and time period differences in American adolescents' religious orientation, 1966-2014. PLoS ONE, 10(5), 1-17. https://doi.org/10.1371/journal.pone.0121454

Tynan, J. J., Somers, C. L., Gleason, J. H., Markman, B. S., \& Yoon, J. (2015). Goal oriented and risk taking behavior: The roles of multiple systems for Caucasian and Arab-American adolescents. School Psychology International, 36(1), 54-76. https://doi.org/10. 1177/0143034314559870

Wagener, L. M., \& Mahoney, H. N. (2006). Spiritual and religious pathology in adolescence. In E. C. Roehlkepartain, P. E. King, L. M. Wagener, \& P. L. Benson (Eds.), The Handbook of spiritual development in childhood and adolescence (pp. 137-149). Sage.

Walcott, C. M., \& Hyson, D. (2018). Results from the NASP 2015 membership survey, part one: Demographics and employment conditions [Research report]. National Association of School Psychologists.

Ward v. WillbanksCase, No. 09-CV-11237 (E.D. Mich. Dec. 13, 2010). https://www.becketlaw.org/case/ward-v-wilbanks/

Wolf, J. T. (2004). Teach, but don't preach: Practical guidelines for addressing spiritual concerns of students. Professional School Counseling, 7, 363-366. https://doi.org/https://www.jstor.org/ stable/42732606

Vieten, C., Scammell, S., Pierce, A., Pilato, R., Ammondson, I., Pargament, K. I., \& Lukoff, D. (2016). Competencies for psychologists in the domains of religion and spirituality. Spirituality in Clinical Practice, 3(2), 92-114. https://doi.org/https://psycnet.apa.org/doi/ $10.1037 / \mathrm{scp} 0000078$

Vieten, C., Scammell, S., Pilato, R., Ammondson, I., Pargament, K. I., \& Lukoff, D. (2013). Spiritual and religious competencies for psychologists. Psychology of Religion and Spirituality, 5(3), 129144. https://doi.org/https://psycnet.apa.org/doi/10.1037/a0032699

Vogel, M. J., McMinn, M. R., Peterson, M. A., \& Gathercoal, K. A. (2013). Examining religion and spirituality as diversity training: A multidimensional look at training in the American Psychological Association. Professional Psychology: Research and Practice, 
44, 158-167. https://doi.org/https://psycnet.apa.org/doi/10.1037/ a0032472

Yarhouse, M. A., \& Tan, E. S. N. (2005). Addressing religious conflicts in adolescents who experience sexual identity confusion. Professional Psychology: Research and Practice, 36, 530-536. https:// doi.org/https://psycnet.apa.org/doi/10.1037/0735-7028.36.5.530

Publisher's Note Springer Nature remains neutral with regard to jurisdictional claims in published maps and institutional affiliations.

Janise S. Parker PhD, LP, LSP, NCSP, is an assistant professor in the school psychology program at William \& Mary. Her research focuses on culturally responsive practice in school psychology, sociocultural factors and positive Black youth development, and implications for supporting spiritually/religiously diverse youth in public school settings.

Kate Murray M.Ed., is a graduate student in the school psychology program at William \& Mary. She has experience conducting research on culturally responsive and social justice-oriented practice in school psychology. Her interests focus on the wholistic support of schoolage youth through culturally responsive school psychological service delivery.
Riley Boegel M.Ed., is a graduate student in the school psychology program at William \& Mary. She has experience conducting research focused on culturally responsive practice in school psychology. Her interest includes the use high-quality comprehensive evaluations to support students with varying exceptionalities.

Madeline Slough M.Ed., is a graduate student in the school psychology program at William \& Mary. Her interests focus on the wholistic support of school-age youth through culturally sensitive school psychological service delivery.

Lee Purvis $\mathrm{PhD}$, LP, NCSP is an assistant professor in the school psychology program at Louisian State University, Shreveport. His research focuses on culturally responsive practice in school psychology and implications for fostering a positive, inclusive school climate for all students.

Christie Geiling M.Ed., is a graduate student in the school psychology program at William \& Mary. Her interests focus on the wholistic support of school-age youth through culturally sensitive school psychological service delivery. 